\title{
Kerusakan dan Pelapukan Material Bata
}

\author{
Oleh \\ Aris Munandar \\ Mantan Karyawan Balai Konservasi Peninggalan Borobudur
}

\section{Pengertian}

Pada dasarnya semua benda yang ada di dunia ini tidak ada yang bersifat abadi, cepat atau lambat benda tersebut akan mengalami proses pelapukan. Kecepatan proses pelapukan yang terjadi sangat ditentukan oleh sifat alami benda (anorganik atau organik) dan faktor lingkungannya.

Kerusakan dan pelapukan mempunyai pengertian yang hampir sama. Akan tetapi secara teknis istilah tersebut dapat dibedakan. Yang dimaksud dengan kerusakan material adalah suatu proses perubahan bentuk yang terjadi pada suatu benda dimana jenis dan sifat fisik maupun kimiawinya masih tetap. Sedangkan yang dimasuk dengan pelapukan adalah suatu proses penguraian dan perubahan dari bahan asli ke material lain dimana jenis dan sifat fisik maupun kimiawi dari material tersebut sudah berubah.

\section{Jenis Kerusakan dan Pelapukan}

Kerusakan dan pelapukan material dapat diklasifikasikan menjadi 4 bagian:

\section{Kerusakan fisis}

Kerusakan fisis adalah jenis kerusakan material yang disebabkan oleh adanya faktor fisis seperti suhu, kelembaban, angin, air hujan, penguapan, gejala yang dapat dilihat adalah mengelupas, retak, pecah-pecah pada kayu, melengkung dan lainlain.

2. Kerusakan mekanis

Yang dimaksud dengan kerusakan mekanis adalah kcrusakan material yang diakibatkan oleh gaya-gaya mekanis seperti, gempa, tekanan/beban, tanah longsor, banjir. Gejala-gejala yang nampak pada kerusakan ini adalah terjadinya keretakan, kemiringan, pecah, dan kerenggangan pada komponen atau struktur bangunan.

3. Pelapukan khemis

Pelapukan khemis adalah pelapukan yang terjadi pada material sebagai akibat dari proses atau reaksi kimiawi. Dalam proses ini faktor yang berperan adalah air, penguapan, suhu. Air hujan dapat melapukkan benda melalui proses oksidasi, karbonatisasi, sulfatasi, dan hidrolisa. Gejalagejala yang nampak pada pelapukan ini seperti penggaraman, korosi, pelapukan batu menjadi tanah perubahan warna pada kayu dan sebagainya.

4. Pelapukan biologis

Pelapukan biologis adalah pelapukan pada material yang disebabkan oleh adanya kegiatan mikroorganisme seperti pertumbuhan jasad, bakteri, serangan binatang seperti rayap, kumbang, kelelawar. Gejala yang nampak pada pelapukan ini adalah diskomposisi struktur material, pelarutan unsur dan mineral, terjadinya noda dan sebagainya.

Gejala kerusakan suatu material biasanya dapat dilihat secara visual, sedangkan gejala pelapukan baru dapat dilihat bila kondisinya sudah tingkat lanjut, sedangkan pada tingkat awal mungkin belum nampak. L'ntuk memastikąn jenis pelapukan tidak cukup hanya dilakukan pengamatan secara visual tetapi jika perlu pengambilan sampel untuk dianalisis di laboratorium.

\section{Faktor-faktor Penyebab \\ Kerusakan dan Pelapukan Material}

Penyebab kerusakan dan pelapukan material dapat dibedakan menjadi 2 faktor, yaitu: faktor internal dan faktor eksternal.

1. Faktor internal

Faktor internal yang berpengaruh terhadap kerusakan dan pelapukan benda meliputi: kualitas dan jenis bahan, tehnologi pembuatan/ struktur bangunan, letak/ posisi bangunan seperti sifat tanah dasar dan letak geografi.

Bangunan yang terbuat dari bahan yang kualitasnya jelek akan cepat mengalami kerusakan. Sedangkan jenis bahan akan berpegaruh terhadap keawetan bangunan, misalnya bangunan yang terbuat dari batu (candi) akan lebih kuat dari pada bangunan yang terbuat dari bata atau kayu pada kondisi lingkungan yang sama.

Sementara struktur bangunan yang dibuat dengan tehnologi yang cukup baik akan memberikan andil yang cukup besar terhadap daya tahan bangunan dari faktor kerusakan yang bersifat mekanis maupun fisik.

Sifat tanah tempat bangunan berdiri, juga mempengaruhi kelestarian material bangunan. Tanah yang mempunyai sitat rentan terhadap faktor air, daya dukungnya akan mudah menurun sehing ga 
menyebabkan kondisi bangunan tidak stabil. Untuk mengeliminir faktor internal dapat dilakukan dengan cara pemugaran maupun konservasi.

2. Faktor eksternal

Faktor eksternal yang berpengaruh terhadap kerusakan dan pelapukan material meliputi faktor fisis (suhu, kelembaban, hujan), faktor biologis, faktor kimiawi, bencana alam, dan faktor manusia. Suhu dan kelembaban yang tinggi dan selalu berubahubah setiap saat akan menyebabkan kondisi benda tidak stabil, yang akhirnya dapat mengakibatkan terjadinya keretakan, pecah, melengkung dan sebagainya.

Air hujan yang membasahi material dapat menyebabkan kelembaban material menjadi tinggi. Keadaan tersebut dapat memicu tumbuhnya jasad renik (ganggang, lumut, jamur) pada permukaan material. Akibat selanjutnya, material akan mengalami kerapuhan, berlubang, menyusut, pecah, dan patah. Faktor eksternal sangat sulit dihindari terutama untuk bangunan yang berada di alam terbuka. Untuk mengurangi efek negatif cara yang terbaik adalah melakukan pemeliharaan secara teratur atau konservasi.

Adakalanya suatu material hanya perlu pemeliharaan saja, agar tidak cepat rusak atau lapuk. Dalam hal ini dapat terjadi apabila faktor umur yang berpengaruh terhadap material tersebut, sedangkan faktor internal maupun eksternal dapat terkendali atau dikendalikan. Material semacam ini biasanya yang berada didalam ruangan.

\section{Permasalahan Konservasi Candi Bata}

Material penyusun bangunan cagar budaya beraneka ragam jenisnya, salah satunya adalah bata. Bata banyak dipergunakan untuk bahan bangunan cagar budaya di wilayah tertentu, misalnya Jawa Timur, Jawa Barat, Bali, Jambi dan Sumatera Barat.

Pada waktu bangunan cagar budaya dari bata ditemukan kadangkadang telah dalam keadaan runtuh dan materialnya hancur. Hal tersebut disebabkan oleh sifat fisik bata yang tidak sekuat material lainnya seperti batu, yang mudah rapuh dan sensitif terhadap ancaman faktor perusak alami baik biologi, fisis maupun khemis seperti pertumbuhan mikroorganisme, pengelupasan, retak, kerapuhan dan penggaraman. Faktor penyebab kerusakan dan pelapukan bata antara lain: air yang masuk ke dalam pori-pori bata melalui proses kapiler, permeabilitas maupun infiltrasi, dan juga faktor lingkungan di sekitar benda cagar budaya berdiri.

Dalam pemugaran bangunan cagar badaya dari bata, pelaksanaannya tidak semudah memugar bangunan cagar budaya dari batu, karena disamping harus hati hati dalam pemasangan kembali setiap blok bata satu sama lain direkatkan kembali dengan sistim gosok. Selain itu pengerjaan bata kuno maupun penggantian bata rapuh dengan bata baru pada bagian luarnya dibentuk dengan cara dipacak. Melihat fenomena tersebut di atas, metode pemugaran bangunan cagar budaya dari bata biasanya dirancang sedemikian rupa sehingga strukturnya kuat dan faktor penyebab kerusakan dapat dieliminir sebanyak mungkin dengan tetap memperhatikan :

1. Konsep otentisitas, yang mencakup otentisitas bahan, desain, tehnologi pengeriaan, serta tata letak.
2. Prinsip-prinsip teknis konservasi yang mencakup efektif, efisien secara teknis maupun ekonomis, tahan lama, aman bagi benda dan lingkungannya

Penanganan konservasi tidak mutlak diperlukan tergantung dari jenis kerusakan dan tingkat pelapukan. Bangunan bata yang tingkat kerusakan tidak serius dan tidak mengancam kelestarian, cukup dilakukan perawatan rutin untuk mencegah kerusakan lebih lanjut yang diakibatkan oleh faktor alami, unsur hayati dan faktor pencemaran.Bila tingkat kerusakan dan pelapukan sangat serius dan dipicu oleh faktor eksternal perlu diambil tindakan konservasi secara menyeluruh yaitu bangunan dan
lingkungannya.

Dalam pelaksanan konservasi dan pemugaran bangunan bata,tanpa disadari sering terjadi kesalahan dalam teknik pengerjaan. Kesalahan tersebut biasanya baru nampak setelah beberapa saat pemugaran berakhir yaitu rusaknya material bata, baik bata asli maupun bat a baru/pengganti, sebagai contoh
misalnya:

1. Pengelupasan permukaan bata pada Candi Tinggi di Muara Jambi sebagai akibat penggunaan massonceal. Hal yang sama juga terjadi di Candi Brahu Jawa Timur, sebagai akibat penggunaan bahan penolak air silicosol.

2. Penggaraman di Candi Jiwa Karawang Jawa Barat, yang disebabkan oleh pemakaian semen PC di dalam struktur bangunan tanpa diolesi lapisan kedap air.

3. Kerapuhan bata pengganti yang sangat cepat pada beberapa candi bata di Jawa Timur yang discbabkan oleh rendahnya kualitasbata. 
Mengapa hal tersebut bisa terjadi? Ada beberapa faktor penyebabnya antara lain perencanaan yang kurang matang dan kurangnya pengetahuan tentang:

a. Sifat-sifat fisik dan kimiawi material bata.

b Faktor dan proses penyebab terjadinya kerusakan dan pelapukan material bata.

\section{Pembuatan Bata Merah}

Bata merah adalah suatu unsur bangunan yang dipergunakan untuk konstruksi bangunan. Bata merah dibuat dari tanah dengan atau tanpa bahan baku lain dibakar cukup tinggi, sehingga tidak dapat larut dalam air. Proses pembuatan bata mulai dari penggalian tanah, pencampuran dengan air dan bahan-bahan lain jika perlu hingga pemberian bentuk semuanya dikerjakan dengan tangan. Ukuran bata merah standar adalah: panjang $230 \mathrm{~mm}$, lebar $110 \mathrm{~mm}$, dan tebal 50 mm (Anonim, 1964; 5-6).

Tanah yang baik sebagai bahan dasar adalah jenis lempung padas, apabila terlalu banyak kandungan lempungnya bata akan mudah pecah pada waktu proses pengeringan, terlebih pada proses pengeringan dengan temperatur yang relatif tinggi, sedang bila terlalu banyak pasir bata akan mudah pecah karena getas. Perbandingan antara lempung dan pasir akan dilakukan oleh pengrajin yang berpengalaman secara alami. Dalam proses pembuatan bata bila terdapat bahan organik seperti akarakar, kayu, dan lain-lain dibersihkan, karena bahan organik mudah terbakar dan dapat berakibat bata menjadi berlubang.

Kualitas bata akan baik, kuat, dan tidak mudah pecah apabila dibakar pada suhu vang tinggi. Bahan bakar yang paling baik adialah kay'u vang kcras, di samping subunva bisa mencapai tinggi juga adanya unsur karbon, sehingga bata menjadi keras (Mulyono, dkk., 1999; 14-15)..Sebaliknya bila dibakar dengan sekam, kekerasannya akan berkurang. Hasil pembakaran bata biasanya permukaan luarnya keras, akan tetapi bila digunakan untuk bangunan candi permukaan yang keras tersebut dipacak akibatnya kekerasannya menurun. Berdasarkan hasil penelitian penurunan kekerasan tersebut mencapai 1 1,5 skala mohs. Kualitas bata biasanya ditunjukkan dari besar kecilnya kuat tekan, sedangkan kuat tekan dipengaruhi oleh suhu/tingkat pembakaran, porositas, dan bahan dasar.

Berdasarkan kuat tekannya, mutu bata merah dapat diklasifikasikan menjadi 3 tingkat, yaitu:

1. Tingkat I, mempunyai kuat tekan rata-rata $<100 \mathrm{~kg} / \mathrm{cm} 2$.

2. Tingkat II, mempunyai tekan antara $80-100 \mathrm{~kg} / \mathrm{cm} 2$.

3. Tingkat III, mempunyai kuat tekan antara $60-80 \mathrm{~kg} / \mathrm{cm} 2$.

Untuk pengujian kualitas bata dapat dilakukan dengan melihat beberapa parameter, diantaranya bentuk; warna massa, kuat tekan, kadar air, dan kadar garam yang larut dan membahayakannya (Anonim, 1964;6).

Bata pada umumnya berwarna merah, tetapi kadangkadang muncul warna lain. Warna kuning menunjukkan pembakaran kurang sempurna, kecuali jika kandungan oksida besi tanah aslinya kurang, sehingga kualitas bata menjadi rendah. Sebaliknya warna yang lebih gelap disebabkan oleh pembakaran yang berlebihan. Perbedaan kualitas bata pada tiap situs dipengaruhi juga oleh teknik pembuatan bata dan bahan baku tanah setempat, serta kondisi lingkungant.
Ketebalan bata sejak berabad abad yang lalu tidak selalu sama. Pada zaman Romawi kuno ketebalan bata antara 30-40 mm,meski pada umumnya adalah 40 $\mathrm{mm}$. Sementara itu pada abad pertengahan variasi ketebalan bata antara $20-40 \mathrm{~mm}$. Pada abad pertengahan terjadi penurunan kualitas bata karena persediaan bahan baku berkurang. Sekitar abad 14-19 ketebalan bata lebih besar yaitu $55 \mathrm{~mm}$.

Berdasarkan naskah Mayamata yang dikembangkan di India Selatan, disebutkan oleh Steel Kramrich yang dikutip Setya Suroso (Dominasi Bata pada Bangunan Candi, Skripsi 1995) menyebutkan tahap-tahap pembuatan bata. Pertama bongkahan tanah dimasukkan kedalam air sedalam lutut, kemudian diaduk-aduk dengan sebelah kaki secara cepat sebanyak empat puluh kali. Selanjutnya diberi air Ksira ( sejenis pohon pohonan), kedamba, Amra (mangga), kulit kayu Abhayaksa, serta air buah amalaka, bahela dan haritaka. Selanjutnya calon bata tersebut dicetak dengan ukuran lebar 4, 5, 6 atau 8 matra (angula) yang merupakan 0,5 ukuran panjangnya. Sedangkan untuk ukuran ketebalan adalah setengah, sepertiga atau sebanding dengan ukuran lebarnva.

Ukuran bata bangunan candi di Jawa Timur berkisar antara : panjang $35 \mathrm{~cm}$, tebal $8 \mathrm{~cm}$ dan lebar $20 \mathrm{~cm}$. Untuk pembuatan bata yang ukurannya sebesar itu perlu keahlian dan pengalaman khusus dalam pencampuran bahan baku terutama tanah/lempung dan pasir, agar pengeringannya mudah dan tidak retak.

\section{Kerusakan dan Pelapukan Material Bata}

Bata merupakan material higroskopis, sehingga mudah 
terpengaruh oleh faktor lingkungan yang menyebabkan bata menjadi lembab. Salah satu faktor yang berpengaruh terhadap kelembaban bata adalah air. Air dapat menyebabkan kelembaban bata meningkat dan dapat menimbulkan kerusakan dan pelapukan bata secara biologis, khemis maupun fisis. Kerusakan biologi tergantung pada besarnya kelembapan pada bata. Algae, jamur, dan lumut akan tumbuh dengan baik pada kelembapan cukup tinggi (Stambolov, 1976;27).

Polusi udara yang bereaksi dengan air akan membentuk cairan asam. Cairan asam dan garamgaram terlarut yang terbawa oleh air akan menimbulkan endapan garam. Keduanya akan menyerang bata dan menyebabkan pelapukan.

Penyebab pelapukan dan kerusakan bata yang terbesar adalah adanya penggaraman pada permukaan bata (Stambolov, 1976;13). Asal endapan garam pada bata kemungkinan berasal dari bahan dasarnya sendiri (tanah), atau selama proses pembakaran. Tetapi sering sekali garam yang merusak ini datang dari luar (Stambolov, 1972; 13).

Kristal-kristal garam dapat merusak bata melalui proses mekanis yaitu berkembangnya Kristal-kristal garam pada pori-pori, kemudian terjadi tekanan sehingga bata menjadi hancur. Kejadian tersebut dapat dijelaskan pada gambar dibawah ini :

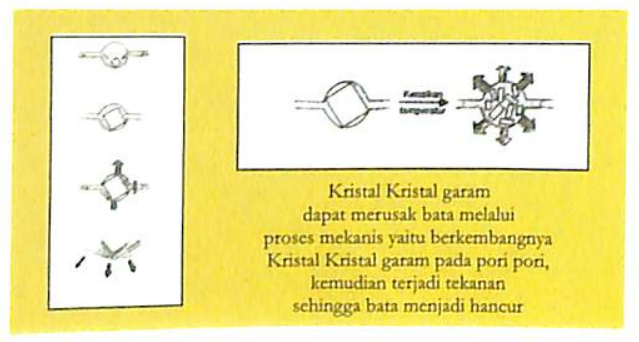

1. Larutan yang melalui pori-pori kecil berpotensi mengendapkan Kristal-kristal garam dari pada pori-pori yang besar.
2. Apabila pori-pori kecil kering dan tidak membawa larutan lagi, endapan kristal garam pada poripori yang besar akan terhenti dan tidak terjadi tekanan.

3. Pori-pori yang besar telah penuh terisi Kristalkristal garam, $\mathrm{s}$ e d a $\mathrm{ngk}$ a $\mathrm{n}$ distribusi larutan melalui pori-pori kecil masih berlanjut, sehingga terjadi pertumbuhan kristal garam pada pori-pori yang besar dan penyumbatan pada pori-pori yang kecil, sehingga terjadi tekanan. Tekanan ini juga dapat terjadi karena adanya kenaikan suhu yang menyebabkan proses dehidrasi pada kristal garam seperti terlihat pada gambar dibawah ini.

Ada tiga kriteria kadar garam yang larut dan membahayakan, (Anonim, 1964; 13):

1. Tidak membahayakan

Bila kurang dari 50\% permukaan bata tertutup oleh lapisan tipis berwarna putih (pengkristalan garam-garam terlarut).

2. Kemungkinan membahayakan Bila $50 \%$ atau lebih permukaan bata tertutup oleh lapisan putih yang agak tebal (pengkristalan garam-garam terlarut), tetapi permukaan bata tidak menjadi bubuk atau terlepas.

3. Membahayakan

Bila lebih dari $50 \%$ permukaan bata tertutup oleh lapisan putih yang tebal (pengkristalan garamgaram terlarut), tetapi bagian dalam dari bata menjadi bubuk dan lepas.

$$
\text { Faktor yang dapat }
$$
mempengaruhi kelembapan bata meliputi kandungan uap air di udara (kelembapan relatif), aliran air secara vertikal maupun horizontal yang melalui material bata.

a. Kelembapan relatif

Kelembapan relatif ialah perbandingan antara banyaknya uap air yang terdapat di udara

Tabel 2.1 Kapasitas udara pada berbagai suhu

\begin{tabular}{|l|l|l|l|l|l|}
-20 & -10 & 0 & 10 & 20 & 30 \\
\hline
\end{tabular}
(Waryono, 1987; 60-6

dengan banyaknya uap air maksimum yang dapat dikandung oleh udara pada suhu dan tekanan yang sama. Kapasitas udara pada berbagai suhu dapat ditulis seperti tabel 2.1 .

Apabila material kering terletak di atmosfer yang mengandung uap air, maka kelembapan relatif

$$
\varnothing=\frac{m \mathrm{H}_{2} \mathrm{O}}{m \text { ker ing }+\mathrm{mH}_{2} \mathrm{O}} \times 100 \%
$$

yang ada di sekitarnya akan diserap oleh material organik dan anorganik. Jumlah uap air yang diserap tersebut, disebut kandungan kelembapan higroskopis yang dapat dihitung dengan rumus:

Untuk material bata yang kelembapannya telah mencapai $95 \%$ dapat dikatakan tidak higroskopis lagi (Stambolov, $1976 ; 17)$.

Kadang-kadang kelembapan meningkat karena beberapa sebab yang bersamaan dengan kerusakan material sehingga menghasilkan kerusakan yang lebih kompleks (Geovani Massari, 1971; 6).

b. Aliran air secara vertikal (kapilarisasi)

Suatu hal yang sering dilupakan dalam pemugaran bangunan bata adalah mencegah terjadinya aliran air secara vertikal, sehingga dinding bangunan selalu lembab sepanjang waktu. 
Pengaruh adanya air kapiler ini dapat menyebabkan kerusakan dan pelapukan bata secara biologis, fisis maupun kimiawi. Proses tersebut akan lebih parah lagi apabila air yang terkapiler mengandung unsur unsur yang korosif terhadap material bata. Pada bangunan bata aliran air

$$
h \max =\frac{15 \times 10^{-6}}{r}
$$

arah vertikal terjadi saat air naik dari dasar dinding, masuk melalui pori-pori bata. Jika tidak terdapat gaya luar yang mempenagruhi, tinggi maximum aliran air arah vertikal yang melewati pori-pori dengan diameter $r$ micron adalah :

Diameter pori-pori bata mempunyai ukuran rata-rata 1 10 mikron, sehingga tinggi kapiler pada bangunan bata antara 15 meter sampai 1,5 meter.

c. Aliran air horizontal

Perpindahan air secara horisontal pada material bata, dapat terjadi melalui sistim permeabilitas (permeabilitas bata $0,3 \times 10-3 \mathrm{~m} /$ ?t sampai dengan $3 \times 10-3 \mathrm{~m} /$ ?t). Air ini dapat berasal dari air kapiler, tampias air hujan dari samping bangunan maupun air hujan yang meresap dari atas bangunan. Proses penetrasi air kadang-kadang menimbulkan endapan garam pada seluruh permukaan bata atau hanya sebagian tergantung dari kondisi permukaan dinding. Pemugaran bangunan bata dengan konstruksi penguat beton dan penggunaan semen $P C$ yang berlebihan tanpa bahan kedap air, aliran air hisontal tersebut merupakan penyebab utama terjadinya endapan garam karena pelarutan kalsium bebas dari beton akan mengendap di permukaan bata oleh proses penguapan.

Selain faktor air, kerusakan dan pelapukan bata dapat juga disebabkan oleh faktor iklim (pengguapan, fluktuasi suhu dan intensitas sinar matahari), misalnya pengelupasan, retakan pada permukaan bata. Kasus pengelupasan bata disebabkan oleh dua hal yaitu desakan garam dan desakan air dari dalam. Pada kasus yang pertama permukaan bata yang mengelupas terdapat endapanendapan garam berwarna putih, sedangkan pada kasus yang kedua permukaan bata yang mengelupas terlihat basah dan menggelembung (gambar desakan dan foto c tinggi kapiler).

Pada sistim lempung air, sebelum bata dibakar didalam strukturnya terdapat berbagai jenis air :

a. Air suspense yaitu pencampuran air dengan bahan dasar

b. Air antar partikel yang terjadi pada waktu melumatkan bahan dasar

c. Air pori antar partikel setelah pengkerutan

d. Air terserap atau terabsorpsi (fisik/kimia) pada partikel

e. Air kisi pada struktur kristalnya

Air vang terabsorpsi fisik hilang pada pemanasan $100^{\circ} \mathrm{C}$. Sedangkan air yang terabsorpsi kimia dalam bentuk ion $\mathrm{H} 3(\mathrm{O}+/ \mathrm{OH}-$ hilang pada suhu $1000^{\circ} \mathrm{C}$. Air gugus hidroksida $(\mathrm{OH})$ mulai lepas pada suhu $600^{\circ} \mathrm{C}$. Dalam proses pembakaran akan terjadi pemampatan, sehingga permukaannya mengecil, volume berkurang dan struktur bata bertambah kuat karena butiran saling menyatu (Anton J,Hartomo,1994,27). ()leh karena itu bata vang suhu pembakarannya kurang dari $600^{\circ} \mathrm{C}$ akanmudah rapuh karena gugus hidroksidanya belum lepas.

Kerapuhan bata dapat terjadi melalui proses fisika dan kimia. Pada proses fisis ikatan butiran akan melemah/hancur karena pengaruh suhu yang menyebabkan terjadinya proses kembang susut pada partikel bata atau adanya tekanan dari partikel lain pada pori-pori bata misalnya garam.

Pada proses kimiawi air berlebihan yang terserap melalui pori-pori bata akan terurai menjadi ion hidroksida $(\mathrm{OH}$ dan ion hidronium $\left(\mathrm{H}_{3} \mathrm{O}^{+}\right)$melalui reaksi

$2 \mathrm{H}_{2} \mathrm{O} \rightarrow \mathrm{H}_{3} \mathrm{O}^{+}+\mathrm{OH}$ kemudian ion hidroksida yang terbentuk akan mengikat ion $\mathrm{Al}$ (Aluminium) menjadi $\mathrm{Al}(\mathrm{OH})_{3}$. Melalui proses hidroksida satu ion silica pada bata akan diganti oleh dua ion aluminium (Anton J,hartomo,1994,14). Dengan demikian bata yang rapuh melalui proses kimiawi unsur $\mathrm{SiO} 2$ mengalami penurunan, sedangkan unsur Al bertambah.

\section{Mengurangi Resiko Kerusakan dan Pelapukan Bata}

Bata akan awet apabila masalah air dapat diatasi, sehingga bata dalam kondisi kering. Dari hasil penelitian menunjukkan bahwa tembok bata yang terlindung dari air hujan dan terbebas kapilarisasi air, kondisinya tetap baik dan bersih meskipun telah lama berdiri di permukaan tanah. Berbeda dengan bata yang terpengaruh air kapiler, kondisinya cepat rapuh dan rusak. Untuk mengatasi masalah air ada beberapa konsep penanganan yang dapat dilakukan:

a. Bangunan bata rang dibongkar secara menveluruh sampai dengan pondasi, perlu dibuat lapisan kedap air yane diletakan pada titik $11 \mathrm{~s} / \mathrm{d} 5 \mathrm{~cm}$ di atas permukaan tanah dan dipilih 
pada bidang horizontal paling lebar. Pada bagian tersebut seluruh permukaannya diolesi bahan kedap air dan celahcelahnya diisi dengan mortar dari bahan kedap air yang sama. Pada bagian atas juga dibuat lapisan kedap air untuk mencegah meresapnya air hujan dari atas.

b. Apabila bangunan bata hanya dibongkar sebagian, lapisan kedap air diletakan pada lapisan paling bawah dari bagian bangunan yang dibongkar dan pilih pada bidang horizontal yang paling lebar. Pada bagian bangunan bata yang tidak dibongkar penangannnya ada 2 cara :

$\checkmark$ Pemasangan geokomposit pada permukaan dinding bangunan yang posisinya dibawah permukaan tanah. Geokomposit ini akan menyerap air yang membasahi dinding candi, kemudian air yang terakumulasi disalurkan ke sistim drainase.

$\checkmark$ Pembenahan ligkungan Dalam konsep ini sebenarnya hanya bersifat mengurang terjadinya kapilarisasi air. Beberapa hal yang perlu dilakukan diantaranya :

- Pembuatan sistim drainase di sekeliling bangunan sehingga air hujan tidak banyak yang meresap ke tanah tetapi langsung melimpas ke sistim drainase atau kemiringan tanah disekitar candi diarahkan keluar.

- model drainase di sekeliling bangunan dengan sistim tertutup dan diberi lapisan penyaring (ijuk) serta kapasitasnya dihitung, sehingga mampu menyalurkan air limpasan dengan baik dan tidak menimbulkan genangan dan luapan air.

- Di sekitar bangunan dibuat sumur-sumur penampungan air dengan kedalaman disesuaikan dengan sratigrafi tanah setempat dan secara periodik air yang berada di dalam sumur dipompa keluar, kemudian dialirkan melalui sistim drainase yang ada.

c. Pada bangunan tembok berplester yang tidak dibongkar ,untuk mengatasi kapilarisasi air dapat ditempuh dengan cara membuat lapisan kedap air pada bagian bawah tembok dengan cara dibor tembus, kemudan bagian yang dibor diisi bahan kedap air atau epoxy resin.

Dari segi teknik, pengerjaan bahan pemugaran dan bahan konservasi dapat dilakukan sebagai berikut:

$\checkmark$ Pemakaian resin silikon (bahan penolak air) hanya dapat dilakukan bila bata benar-benar telah terbebas dari air kapiler maupun air rembesan. Dari hasil penelitian menunjukan bahwa pengolesan bahan penolak air dengan tujuan untuk mengurangi kelembaban dan jumlah air yang masuk ke dalam material bata ternyata efektif selama masalah air telah teratasi.

$\checkmark$ Penggunaan PC semen untuk penggosokan bata bila perlu saja dan dibatasi seminimal mungkin, hal ini untuk menjaga pelarutan kalsium bebas.

$\checkmark$ Beton untuk perkuatan struktur perlu diolesi lapisan kedap air, bila masalah air belum bisa diatasi sepenuhnya.

$\checkmark$ Untuk mengha mbat pertumbuhan mikroorganisme dapat dilakukan pengawetan dengan bahan herbisida algaesida dan fungisida. Sedangkan untuk perbaikan bata yang rusak dan bata yang rapuh dapat digunakan bahan konservasi yang telah teruji di laboratorium.

$\checkmark$ Untuk penggantian bata (bata pengganti), sebaiknya kualitasnya diuji lebih dahulu sebelum digunakan, atau pesan pada pengrajin langsung.

Adapun parameter yang diuji meliputi:

$\checkmark$ Campuran bahan dasar

$\checkmark$ Suhu pembakaran

$\checkmark$ Kuat tekan

$\checkmark$ Porositas

$\checkmark$ Kadar garam terlarut

$\checkmark$ Warna, berat, bentuk dan kadar penyerapan air

Untuk bangunan bata yang runtuh dan masih menunggu waktu untuk dipugar penanganannya adalah sebagai berikut:

$\checkmark$ Dibuat atap yang melindungi seluruh bangunan.

$\checkmark$ Dibuat sistem drainase yang sempurna disekeliling bangunan. $\square$

\section{Daftar Pustaka}

Anonim. Water Movement in Porous Solids.

Anonim,1964, Bata Merah Sebagai Bahan Bangunan N-10, Departemen Pekerjaan Umum dan tenaga listrik Yakarta.

Antono A,1971, Ilmu Bahan Konstruksi Teknik.

Croci,G, 1998, The Conservation and Structural Restoration of Architectural Heritage, Computacional Mechanics Publications, Southampton, $\mathrm{U}$ $\mathrm{K}$ and Boston, USA. 
D a y Tr, R. A a n d A. L Underwood,1989, Analisis Kimia Kuantitatif ,Erlangga Jakarta.

Hartomo,AJ,1994. Mengenal Keramik Modern, Andi Offset, Yogyakarta.

Massari ,G,1971, Humidity in Monument, Faculty of Architecture, Universityu of Rome, ICSPRCP,Roma.

Nuryadi, 1996, Laporan Pelaksanaan Pemugaran Candi Candi Bata di Trowulan, Departemen Pendidikan dan Kebudayaan.

Stambolov,T and JRJ,Van Asperen de Boer,1976, The Deteroration and Conservation of Porous Building Materals in Monument, 2nd ICSPRCP, Roma.

Waryono, R,A Rifai dan DH Gunawan ,1987, Pengantar Meteorologi dan Klimatologi untuk Universitas dan Umum, Pt Bina Ilmu, Yakarta.

Mulyono dkk, Studi Teknis Pengerja a $B$ ah a n Pemugaran Bata, Balai Studi dan Konservasi Borobudur

Munandar A,dkk, Studi Pengaruh Kapilarisasi Air pada Bangunan Bata, Balai Studi dan Konservasi Borobudur 2000.

Munandar A, Perawatan dan Pengawetan Bangunan Bata, Balai Studi dan Konservasi Borobudur, 2002.

Munandar A,dkk ,Studi Teknik Pengerjaan Bahan Pemugaran Candi Bata, Balai Studi dan Konservasi Borobudur, 2001-2003.
Contoh Jenis Kerusakan Bata
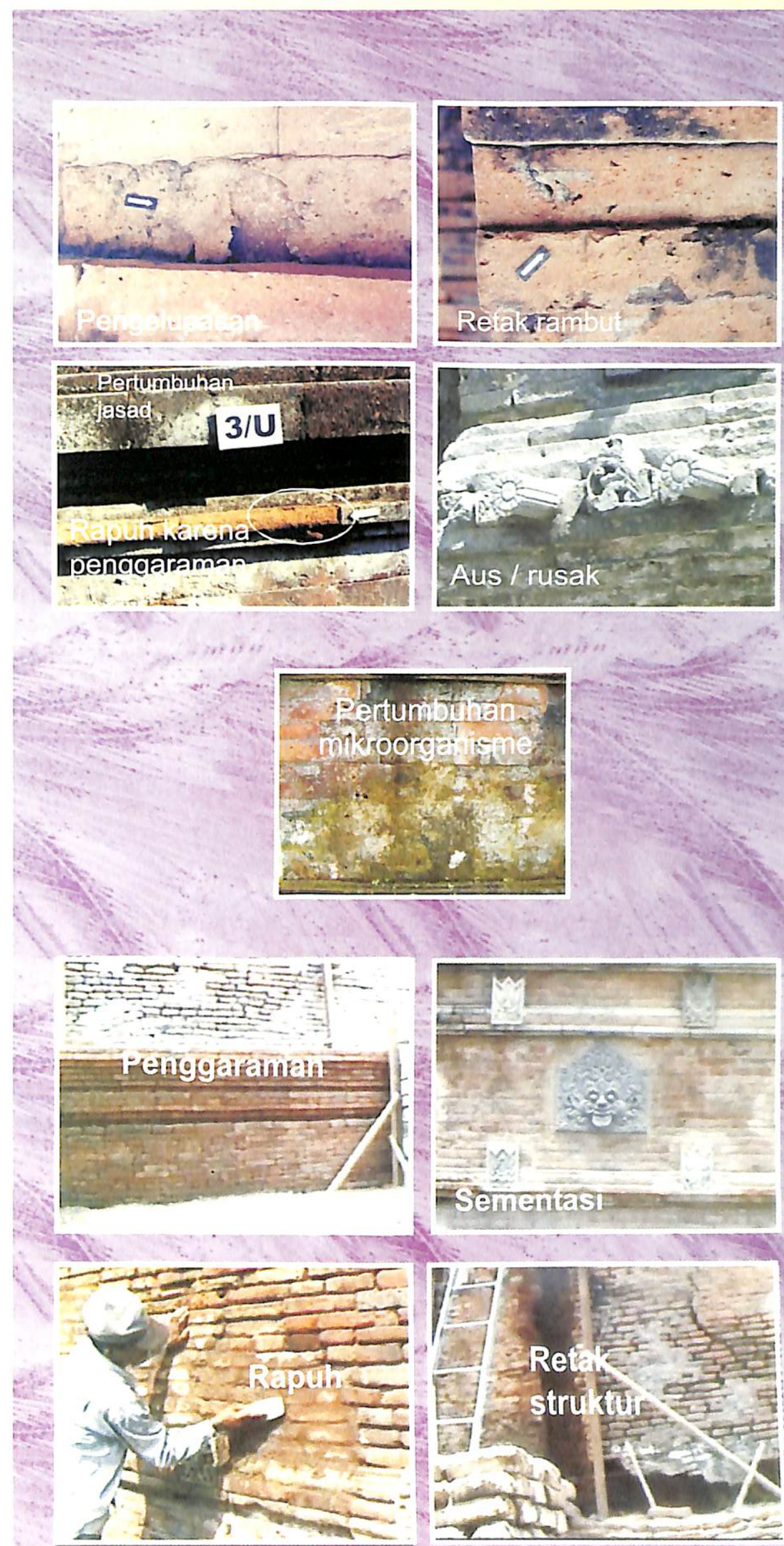